\title{
Potensi Kerabang Telur dalam Pakan Ayam Ras Telur Telur
}

\author{
Potention Of Egg Shells in Ration Of The Layer Chicken \\ Sumiati*, Erwan, Dwi Kusuma Purnamasari, Syamsuhaidi, Suhartini \\ Laboratorium Ilmu Nutrisi dan Makanan Ternak Non Ruminansia \\ Fakultas Peternakan Universitas Mataram \\ Jalan Majapahit No.62 Mataram 83125, NTB, Indonesia \\ Telepon (0370) 633603.Fax (0370)640592 \\ *Corresponding Author Email: sumiatiunram@ic.id
}

Manuscript received: 04-07-2021. Accepted: 27-10-2021

\begin{abstract}
ABSTRAK
Penelitian bertujuan untuk mengetahui potensi tepung kerabang telur dalam pakan terhadap produksi dan kualitas telur ayam ras. Materi yang digunakan adalah ayam ras petelur berumur 7 bulan sebanyak 75 ekor yang dikelompokkan menjadi 3 kelompok perlakuan (P1,PII,PIII) dan tiap kelompok terdiri dari 5 ulangan, tiap ulangan terdiri dari 5 ekor ayam. Pakan yang diberikan tersusun dari $34 \%$ konsentrat KLKS $+50 \%$ jagung kuning $+16 \%$ dedak padi (P1), $34 \%$ konsentrat KLKS $+50 \%$ jagung kuning+ $14 \%$ dedak padi $+5 \%$ kerabang telur (PII), konsentrat KLKS $34 \%+50 \%$ jagung kuning $+14 \%$ dedak padi $+7 \%$ kerabang telur (PIII). Pariabel yang diukur adalah produksi telur, berat telur, konsumsi pakan, konversi pakan, kualitas eksternal telur. Data yang diperoleh dianalisis dengan analisis varians atas dasar rancangan acak lengkap. Hasil penelitian menunjukkan bahwa produksi telur, berat telur, konsumsi dan konversi pakan, ayam ras yang diberikan kerabang telur dalam pakan antara perlakuan PI, PII dan PIII berpengaruh tidak nyata $(\mathrm{P}>0.05)$ namun berpengaruh nyata terhadap berat dan tebal kerabang telur $(\mathrm{P}<0.05)$. Disimpulkan bahwa pemberiann kerabang telur sampai level $7.5 \%$ dalam pakan cukup berpotensi dalam meningkatkan produksi dan kualitas eksternal telur ayam ras petelur dengan efisiensi pakan yang reletif baik.
\end{abstract}

Kata kunci: kerabang telur; produksi telur; kualitas telur; ayam ras

\footnotetext{
ABSTRACT

The aim of this research is to know potention of the egg shells mill in ration toweard eggs production and Quality of the layer chiken. This research was conducted in August 2020 at Apitaik West Lombok, laboratory of Animal nutrition Animal Husbandri Mataram Univercity and laboratory of BPTP East Nusa Tenggara. 75 of layer chiken devide into 5 treatment was PI ( $0 \%$ egg shells $+50 \%$ yellow corn $+16 \%$ rise bren and $36 \%$ KLKS consentrat), P1I (5\% eggs shells $+50 \%$ yellow corn $+16 \%$ rise bren and $36 \%$ KLKS consentrat), P1II (7\% eggs shells $+50 \%$ yellow corn, $36 \%$ KLKS consentrat) $+16 \%$ rise bren), 5 replicetes and each replicates use 5 layer chiken and all of treatment give iso protein and iso energy ration. The parameter in this reaserch was eggs production, feed comsumtion, feed convertion, eggs weight and eggs quality. The result of this research were analysis by varians analysis above
} 
completely randomized design (CRD). The result showed that eggs producktion, eggs weight, feed cosumtion and feed convertion non significant effect $(\mathrm{P}>0.05)$, but was significant effect $(\mathrm{P}<0.05)$ on weight and thick of eggs shell It was concluded that giving egg shells to a level of $7.5 \%$ in the feed had enough potential to increase egg production and quality of laying hens with relatively good feed efficiency.

Keywords: egg shell; egg production; Egg quality; purebred chicken

\section{PENDAHULUAN}

Ayam Ras Petelur adalah salah satu jenis ternak unggas yang sangat popular dikembangkan di kalangan masyarakat, baik dalam skala kecil yang dikelola oleh keluarga atau sekelompok masyarakat peternak maupun dalam bentuk Industri Peternakan dalam skala usaha yang cukup besar. Banong (2012) mengemukakan bahwa ayam petelur dibagi menjadi tiga fase, yaitu fase starter (umur 1 hari - 6 minggu), fase grower pertumbuhan (umur 6-18 minggu), dan fase layer/petelur (umur 18 minggu-afkir). Khususnya fase grower, fase ini sangat berpengaruh pada saat fase produksi atau fase layer. Cahyono (1995) menyatakan ayam petelur merupakan ayam betina dewasa yang dipelihara khusus untuk diambil telurnya dengan jumlah produksi telurnya antara 250 sampai 280 butir per tahun.

. Sudarmono (2003) menyatakan bahwa produksi telur yang baik akan di peroleh pada tahun pertama ayam mulai bertelur dengan puncak produksi pada umur 7-8 bulan dan pada tahun-tahun berikutnya cenderung akan terus menurun.

Tingkat produktivitas ternak termasuk produksi telur ayam ras dipengaruhi oleh adalah antara lain, manajemen pemeliharaan, lokasi kandang, kondisi pasar faktor infeksius (penyakit) dan faktor non infeksius. kualitas pakan yang diberikan terutama kandungan proteinnya (Amrullah.2003., Anonim, 2012, Anonim. 2017)). Rahardjo,Y (2009) menyatakan faktor penyebab turunnya produksi telur antara lain kualitas telur, mutu bibit, kecukupan nutrisi, kesehatan ayam, kondisi lingkungan dan tatalaksana pemeliharaan, perkembangan saluran pencernaan dan reproduksi, umur ternak, lama penyinaran dan stress, kurangnya lama penyinaran dan lelah kandang. Selanjutnya Scott (1984) menyatakan bahwa tingkat produktivitas ternak termasuk produksi telur sangat dipengaruhi oleh kualitas pakan yang diberikan. Kualitas pakan yang diberikan pada ternak akan berpengaruh terhadap jumlah pakan yang dikonsumsi. Tillman et al. (1989) menyatakan bahwa konsumsi ransum dipengaruhi oleh lingkungan, imbangan zat-zat makanan, kualitas ransum, bangsa ternak, kecepatan pertumbuhan, bobot badan, tingkat produksi, palatabilitas ransum dan tingkat energi ransum. Lebih lanjut Tillman et al. (1989) menyatakan konsumsi ransum dipengaruhi oleh lingkungan, imbangan zat-zat makanan, kualitas ransum, bangsa ternak, kecepatan pertumbuhan, bobot badan, tingkat produksi dan palatabilitas ransum.

Produksi telur berhubungan langsung dengan konversi pakan, semakin tinggi produksi telur (kg) yang dihasilkan semakin kecil nilai konversi pakan( Wahju,J.1997. Apabila nilai konversi pakan semakin kecil maka konversi pakan baik, berarti ayam petelur dapat menggunakan pakan dengan baik dan dapat menghasilkan produksi telur dengan baik. Produksi telur dapat ditentukan dengan menghitung Hen-day Production 
Hen-day Production setiap strain ayam petelur berbeda-beda. Standar Hen-day Production strain ayam petelur Hisex, Hyline, ISA Brown, Lohmann HD puncak produksi 96\%, 94-96\%, 95\%, 94.5\% (Wahyuni, 2008). Rumus yang dipakai dalam perhitungan HDP yaitu:

\section{HDP $=\underline{\text { Jumlah telur }} \quad \mathrm{x} 100 \%$ \\ Jumlah induk $\mathrm{x}$ hari}

Telur ayam ras adalah salah satu sumber protein hewani yang populer dan sangat diminati oleh masyarakat. Hal ini karena telur ayam ras relatif murah dan mudah diperoleh serta dapat memenuhi kebutuhan gizi yang diharapkan (Sumiati.at al, 2016). Telur ayam negeri punya ukuran atau berat lebih besar dan punya cangkang yang teskturnya kasar bila dibandingkan dengan telur ayam ras.

Menurut Yuwanta (2010) berat telur akan terus meningkat secara cepat pada 6 minggu pertama setelah bertelur. Kenaikan berat telur ini disebabkan oleh meningkatnya jumlah putih telur sedangkan berat kuning telur relatif stabil. Berat telur ternak di daerah yang beriklim tropis berkisar 40-45. Anggorodi (1995) menambahkan besarnya telur dipengaruhi oleh banyak faktor termasuk sifat genetik, umur ternak, tingkatan dewasa kelamin, umur, obatobatan dan kecukupan protein dan asam amino dalam pakan. ukuran telur. Sedangkan menurut Harmayanda et al,. (2016) menjelaskan bahwa kandungan kalsium dan fosfor dalam pakan berperan terhadap kualitas ekternal kerabang telur, seperti ketebalan, berat dan struktur kerabang telur. Semakin tua umur ayam maka semakin tipis kerabang telurnya, hal ini terjadi karena ayam tidak mampu untuk memproduksi kalsium yang cukup guna memenuhi kebutuhan kalsium dalam pembentukan kerabang telur (Yuwanta, 2010). Sedangkan kualitas internal meliputi indeks albumen, indeks yolk, berat yolk, warna yolk dan nilai haught unit. SNI 013926-2008 (2008) menyatakan bahwa indeks putih telur merupakan perbandingan antara tinggi putih telur dengan diameter rata-rata putih telur kental. Indeks putih telur segar berkisar antara 0,050-0,174. Sedangkan indeks kuning telur adalah perbandingan tinggi kuning telur dengan garis tengah kuning telur.

Sampai saat ini usaha peternakan masih dihadapkan dengan permasalahan pakan yaitu adanya pluktuasi harga pakan sehingga masyarakat peternak cendrung mencari bahan pakan alternatif guna menekan biaya pakan. Bahan pakan alternative yang cukup potensial, baik dari segi kualitas maupun kuantitas antara lain adalah tepung kerabang telur. Kerabang telur merupakan bagian telur yang paling keras dan kaku yang mengandung nutrisi tinggi terutama mineral kalsium sehingga dapat dijadikan sebagai bahan pakan sumber mineral. Syahputra.A (2006) menyatakan bahwa tepung kerabang telur dapat digunakan sebagai perekat karena mengandung $98 \%$ kalsium karbonat $\left(\mathrm{CaCO}_{3}\right)$. Produksi telur secara Nasional setiap tahun terus meningkat mencapai 3,6\% (Kementrian Pertanian-Direktorat jendral Peternakan.2016) hal ini akan berpengaruh terhadap jumlah kerabang telur. Selanjutnya produksi telur di Nusa Tenggara Barat pada tahun 2016 sampai dengan tahun 2018 rata-rata sebanyak 9.020,84 ton (Badan Pusat Statistik.2020). Sumiati,dkk (2018) bahwa porsi kerabang dari satu butir telur adalah sekitar $11-11,7 \%$, maka limbah kerabang telur yang dihasilkan di Nusa Tenggara Barat pada tahun 2018 sekitar 992,3 ton- 1,055,44 ton. Penggunaan kerabang telur di Nusa Tenggara Barat 
sebagai bahan pakan ternak belum dimanfaatkan bahkan dibuang sehingga dapat mencemari lingkungan. Kerabang telur merupakan bagian telur yang paling keras dan kaku yang mengandung nutrisi tinggi terutama mineral kalsium sehingga dapat dijadikan sebagai bahan pakan sumber mineral. Dengan demikian merupakan suatu hal yang sangat bijak kalau perhatian ditujukan kepada limbah telur dalam hal ini adalah kerabang telur ayam Ras Berdasarkan uraian diatas maka perlu dilaksanakan penelitian untuk mengkaji potensi kerabang telur dalam pakan terhadap produksi telur ayam ras sehingga dapat diperoleh ransum yang berkualitas dan produksi telur yang berkualitas yang pada akhirnya akan meningkatkan pendapatan masyarakat khususnya masyarakat peternakan.

\section{BAHAN DAN METODE}

Penelitian untuk mengetahui potensi kerabang telur dalam pakan terhadap produksi telur ayam ras telah dilaksanakan di Desa Apitaik kecamatan Pringgabaya kabupaten Lombok Timur selama 5 bulan. Untuk analisis calcium dan posfor kerabang telur dilakukan di Laboratorium BPTP Nusa Tenggara Barat dan uji kualitas eksternal dan internal telur dilakukan di Laboratorium Teknologi Pengolahan Hasil Ternak Fakultas Peternakan Universitas Mataram.

Materi yang digunakan adalah ayam ras petelur sebanyak 75 ekor umur 7 bulan yang dikelompokkan menjadi 3 kelompok perlakuan (PI,PII,PIII)dengan 5 ulangan dan masingmasing ulangan terdiri dari 5 ekor ayam. Pakan yang diberikan tersusun dari $34 \%$ konsentrat layer+50\% jagung kuning+16\% dedak padi+0,5\% Top Mix (P1)., 34\% konsentrat layer+50\% jagung kuning $+14 \%$ dedak padi+0,5\% Top Mix $+5 \%$ kerabang telur (PII).,dan $34 \%$ konsentrat layer $+50 \%$ jagung kuning $+14 \%$ dedak padi $+0,5 \%$ Top Mix $+7,5 \%$ kerabang telur (PIII).

Peralatan yang digunakan dalam penelitian ini meliputi kandang individu sebanyak 75 unit lengkap dengan tempat pakan dan air minum, Timbangan kapasitas $15 \mathrm{~kg}$ untuk menimbang pakan, terpal, seperangkat peralatan untuk analisis kualitas eksternal dan internal telur.

Penelitian ini dimulai dengan beberapa tahapan yaitu:

\section{Pembuatan Tepung Kerabang Telur.}

Kerabang telur yang akan diolah menjadi tepung, akan diperoleh dari masyarakat yang bergerak dibidang usaha pembuatan roti, martabak, terang bulan yang ada di kota Mataram. Kerabang telur direndam dengan air yang mempunyai suhu $80{ }^{\circ} \mathrm{C}$ selama 30 menit kemudian dijemur sampai berat konstan. Kerabang telur digiling halus dicampur dengan bahan lain dan pakan siap diberikan pada ternak.

\section{Persiapan Kandang Dan Ayam.}

Kandang yang akan digunakan adalah kandang baterai sebanyak 75 unit yang dilengkapi dengan tempat pakan dan air minum. Kandang akan diberi tanda sesuai kelompok dan ulangan.

\section{Pembuatan Pakan.}

Pakan untuk masing-masing perlakuan tersusun dari jagung kuning,dedak padi halus, 
konsentrat layer (pakan basal) tepung kerabang telur,premix mineral dengan iso protein dan iso energi.

Persiapan Ayam.

Tujuh puluh lima (75) ekor ayam dikelompokkan menjadi 3 kelompok perlakuan ,tiap perlakuan terdiri dari 5 ulangan dan setiap ulangan terdiri dari 5 ekor ayam. Selanjutnya ayam dimasukkan dalam kandang individu sesuai perlakuan.

\section{Analisis Kandungan Nutrient Kerabang Telur.}

Kerabang telur yang sudah digiling disampling sebanyak $500 \mathrm{~g}$, dibawa ke laboratorium untuk dianalisa kandungan Calsium (Ca) dan pospor (P) dengan metode AOAC(1990) masingmasing 3(tiga) kali ulangan. Analisis kandungan nutrient akan dilakukan di Laboratorium BPTP Nusa Tenggara Barat.

\section{Pemberian Pakan Dan Air Minum.}

Ayam yang sudah dikelompokkan sesuai perlakuan diberikan pakan dan air minum secara adlibitum.

\section{Koleksi Data.}

Data yang akan dikoleksi berupa produsi telur harian, konsumsi pakan, konversi pakan dan berat telur dikoleksi dan diukur selama penelitian yaitu 4 minggu.

\section{Pengambilan Sampel Telur.}

Pengambilan sampel dilakukan 2 kali selama penelitian yaitu pada minggu ke II dan ke IV setelah pemberian perlakuan, masing-masing perlakuan sebanyak 2 butir setiap ulangan. Jadi jumlah sampel telur yang digunakan sebanyak 60 butir telur.

\section{Pengukuran Kualitas Eksternal Telur.}

Kualitas eksternal telur yang diukur dalam penelitian ini meliputi berat kerabang telur dan tebal kerabang telur. Berat kerabang diukur dengan cara menimbang kerabang telur dengan timbangan merek Ohaus sedangkan tebal kerabang telur diukur dengan menggunakan jangka sorong

\section{Variabel yang Diamati.}

Variabel yang Diamati.dalam penelitian ini meliputi produksi harian telur selama 4 minggu dihitung dengan rumus

$$
\text { HDP }=\frac{\text { Jumlah telur }}{\text { Jumlah induk }} \times \text { Jumlah hari } \times 100 \%,
$$

berat telur, konsumsi pakan, konversi pakan, kualitas eksternal telur (berat kerabang dan tebal kerabang telur) .

Selanjutnya data yang diperoleh dalam penelitian ini dianalisis dengan analisis Varians atas dasar rancangan acak lengkap. 


\section{HASIL DAN PEMBAHASAN}

Hasil penelitian tentang potensi kerabang telur dalam pakan terhadap produksi telur ayam ras dalam pakan terhadap produksi dan kualitas telur tertera pada table 1 .

Tabel 1. Rerata konsumsi pakan, produksi telur, berat telur, konversi pakan

Dan kualitas eksternal telur ayam ras tiap perlakuan selama penelitian.

\begin{tabular}{lccc}
\hline Variabel & \multicolumn{3}{c}{ Perlakuan } \\
\cline { 2 - 4 } & P0 & P1 & P2 \\
\hline $\begin{array}{l}\text { Konsumsi pakan } \\
\text { (g/ekor/hari) }\end{array}$ & $104.69^{\mathrm{a}}$ & $102.04^{\mathrm{a}}$ & $104.92^{\mathrm{a}}$ \\
Produksi Telur (\%) & & & \\
Bobot Telur (g/butir) & $71.43^{\mathrm{a}}$ & $71.36^{\mathrm{a}}$ & $78.14^{\mathrm{a}}$ \\
Konversi pakan & $60.46^{\mathrm{a}}$ & $58.52^{\mathrm{a}}$ & $58.19^{\mathrm{a}}$ \\
Berat Kerabang (g/butir) & $2.26^{\mathrm{a}}$ & $2.72^{\mathrm{a}}$ & $2.35^{\mathrm{a}}$ \\
Tebal Kerabang (mm/butir) & $7.30^{\mathrm{a}}$ & $7.80^{\mathrm{ab}}$ & $8.17^{\mathrm{b}}$ \\
& $0.44^{\mathrm{a}}$ & $0.50^{\mathrm{b}}$ & $0.53^{\mathrm{b}}$
\end{tabular}

Keteragan: Superskrip $\left.{ }^{(\mathrm{a}, \mathrm{b}}\right)$ yang berbeda pada kolom menunjukan perbedaan yang nyata pada taraf $(\mathrm{P}<0,05)$

\section{Konsumsi Pakan.}

Konsumsi pakan ayam ras petelur pada masing-masing perlakuan dalam penelitian ini seperti pada tabel 5.sebesar 104.69g/ekor/hari (PI), 102.04 g/ekor/hari (PII) dan 104,92g/ekor/hari. Hasil analisis statistik menunjukan bahwa potensi tepung kerabang telur dalam pakan terhadap konsumsi pakan ayam ras petelur selama penelitian pada setiap perlakuan baik pada perlakuan PI (0\% kerabang telur), PII (5\% kerabang telur), maupun PIII (7\% kerabang telur), tidak memberikan pengaruh yang nyata $(\mathrm{P}<0.05)$. Hal ini berarti bahwa kualitas dan palatabilitas pakan dari ketiga perlakuan relatif sama dimana ransum dari ketiga perlakuan dalam penelitian ini mempunyai kandungan zat gizi dalam kisaran jumlah yang dibutuhkan. Di samping kualitas ransum yang relatif sama, juga disebabkan oleh umur ayam yang digunakan dalam penelitian ini sama yaitu 7 bulan. Hal ini di perkuat oleh pendapat, Tillman et al., (1989) menyatakan bahwa konsumsi ransum dipengaruhi oleh lingkungan, imbangan zat-zat makanan, kualitas ransum, bangsa ternak, kecepatan pertumbuhan, bobot badan, tingkat produksi, palatabilitas ransum dan tingkat energi ransum. Menurut Wulandari (2000) konsumsi pakan dipengaruhi oleh beberapa faktor antara lain umur ternak, kandungan protein dalam ransum, genetik, kepadatan dalam kandang, penyakit. Lebih lanjut Tillman et al (1989) menyatakan konsumsi ransum dipengaruhi oleh lingkungan, imbangan zat-zat makanan, kualitas ransum, bangsa ternak, kecepatan pertumbuhan, bobot badan, tingkat produksi dan palatabilitas ransum.

\section{Poduksi Telur}

Rata-rata produksi telur (HDP) setiap perlakuan yang diperoleh selama penelitian masing-masing sebesar 71,43\% (PI)., 71 36\% (PII) dan 78.14\% (PIII). Hasil rata-rata produksi telur antara perlakuan P0 dengan PI,PII dan PIII secara statistic menunjukkan pengaruh yang tidak nyata $(\mathrm{P}>0,05)$. Tidak adanya perbedaan produksi telur antara perlakuan PI,PII maupun PIII, disebabkan konsumsi pakan antara ketiga perlakuan sama, hal ini dapat menyebabkan daya cerna dari pakan 
pada keempat perlakuan sama yang berpengaruh pada konsumsi pakan yang pada akhirnya berpengaruh pada produksi telur.

Anonim (2017) menyatakan ada tiga factor yang mempengaruhi tingkat produksi telur ayam ras yaitu kualitas ransum, baik dari segi kualitas maupun kuantitas, factor lingkungan dan lokasi kandang. Anonim (2012) bahwa faktor-faktor penyebab utama terjadinya penurunan produksi pada peternakan ayam petelur, yaitu faktor infeksius (penyakit) dan faktor non infeksius.

Rahardjo,Y (2009) menyatakan faktor yang dapat menyebabkan produksi telur yang turun dan sering terkait satu sama lain yaitu: kualitas telur itu sendiri, mutu bibit, kecukupan nutrisi, kesehatan ayam, kondisi lingkungan, dan tatalaksana pemeliharaan, perkembangan saluran pencernaan dan reproduksi, umur ternak, lama penyinaran dan stress, kurangnya lama penyinaran dan lelah kandang. Selanjutnya dinyatakan bahwa, untuk mencapai produksi telur yang optimal maka harus disertai dengan konsumsi ransum yang cukup. Nafsu makan yang turun dapat menghasilkan berat telur yang rendah.

\section{Berat Telur}

Rata-rata berat telur perekor setiap perlakuan yang diperoleh selama penelitian masingmasing sebesar 60.465g/butir (PI), 58.52 g/butir (PII) dan 58.19 g/butir (PIII). Nampak bahwa bobot telur ayam yang diperoleh tertinggi pada perlakuan PI diikuti perlakuan PII, PIII dan terendah pada perlakuan PII. Bila dibandingkan dengan berat telur standar yang dinyatakan Sumarni dan Duarnani (1995) yang menyatakan bahwa klasifikasi standar berat telur meliputi jumbo ( diatas 76g), extra larg (70-77g), larg (64-70g), medium (58-64g), medium small (52$58 \mathrm{~g}$ ) dan small (kurang dari 52g, maka berat telur yang diperoleh dalam penelitian ini termasuk dalam standar medium yaitu 58-64 gram.

Hasil rata-rata bobot telur antara ketiga perlakuan PI, PII dan PIII secara statistic menunjukkan pengaruh yang tidak nyata $(\mathrm{P}>0.05)$. Hal ini seiring dengan konsumsi pakan antara ketiga perlakuan yaitu tidak menunjukkan adanya pengaruh yang nyata sehingga penyerapan nutrisi ayam untuk kebutuhan dalam meningkatkan berat telur pada semua perlakuan relative sama (Sirait,C.H.1986). Hal ini sesuai pendapat Anggorodi (1994) bahwa besarnya telur dipengaruhi oleh banyak faktor termasuk sifat genetik, tingkatan dewasa kelamin, umur, obat-obatan dan pakan. Faktor makanan terpenting yang diketahui mempengaruhi besar telur adalah protein dan asam amino yang cukup.

\section{Konversi Pakan}

Konversi pakan erat kaitannya dengan efisiensi penggunaan ransum selama proses produksi dan didefinisikan sebagai perbandingan antara konsumsi pakan dengan jumlah produksi telur (Rasyaf, 1993). Rata - rata koversi pakan ayam yang diperoleh selama penelitian untuk masing-masing perlakuan adalah sebesar 2.26 (PI), 2.72 (PII), 2.35 (PIII). Dijelaskan lebih lanjut oleh Rasyaf (2009) menyatakan bahwa tingkat konversi pakan yang berbeda-beda tergantung kadar protein dan energi metabolisme pakan, suhu lingkungan, umur ayam, kondisi kesehatan dan komposisi pakan. Apabila nilai konversi pakan semakin kecil 
maka konversi pakan baik, berarti ayam petelur dapat menggunakan pakan dengan baik dan dapat menghasilkan produksi telur dengan baik. Hasil analisis statistic menunjukkan bahwa konversi pakan ayam ras petelur dalam penelitian ini adalah memberikan pengaruh yang tidak nyata

(P >0.05) antara perrlakuan PI, PII dan PIII. Hal ini berarti bahwa tingkat efisiensi pakan antara ketiga perlakuan memberikan nilai ekonomis yang sama dalam memproduksi telur. Tidak adanya perbedaan konversi pakan antara perlakuan disebabkan berat telur dan konsumsi pakan yang diperoleh dalam penelitian ini

\section{Berat Kerabang Telur}

Berat kerabang telur ayam ras petelur yang diberi pakan dengan campura tepung kerabang telur yang berbeda pada tiap perlakuan memiliki berat rata-rata seperti pada Tabel 2 yaitu $7.30 \mathrm{~g} /$ butir (P0); $7.80 \mathrm{~g} /$ butir (P1); dan $8.17 \mathrm{~g} /$ butir (P2).

Dari hasil analisis menunjukkan bahwa ayam ras yang diberi tepung kerabang telur pada semua perlakuan memberikan pengaruh yang berbeda nyata $(\mathrm{P}<0.05)$ terhadap berat kerabang telur. Hal ini disebabkan karena adanyan perbedaan persentase penggunaan kalsium dan fosfor dalam pakan. Kandungan kalsium yang relatif berbeda tersebut dimamfaatkan dan direspon dalam bentuk berat kerabang telur yang berbeda pula. Sehingga hasil yang didapatkan semakin tinggi penambahan kalsium dalam pakan maka semakin tinggi pula berat kerabang telur yang dihasilkan.

\section{Tebal kerabang telur}

Rata-rata tebal kerabang telur ayam ras yang diperoleh dalam penelitian ini seperti tertera pada Tabel 1. masing-masing sebesar 0,44 mm/butir (P0); $0.50 \mathrm{~mm} /$ butir (P1) dan 0,53 $\mathrm{mm} /$ butir (P2). Hasil penelitian ini lebih tinggi dibandingkan dengan pendapat Idris dan Thohari (1998) yang menyatakan bahwa tebal kerabang telur ayam yang ideal yaitu berkisar antara $0.33-0.36 \mathrm{~mm}$.

Dari hasil analisis statistik menunjukkan bahwa rata-rata tebal kerabang telur ayam ras petelur yang ditambahkan tepung kerabang telur dalam pakan memberikan pengaruh yang berbeda nyata $(\mathrm{P}<0.05)$ pada perlakuan $\mathrm{P} 0, \mathrm{P} 1$, maupun $\mathrm{P} 2$. Hal ini disebabkan karena persentase penggunaan kalsium dan fosfor dalam pakan berbeda sehingga hasil yang didapatkan berbeda pula. Hal ini sesuai dengan pendapat Sarwono (1994), yang menyatakan bahwa unggas yang diberi pakan dengan kandungan kalsium tinggi, biasanya menghasilkan kerabang telur yang tebal sedangkan ketebalan kerabang telur akan berpengaruh terhadap berat kerabang. Jadi kualitas kerabang telur ditentukan oleh ketebalan dan struktur kerabang. Semakin tinggi konsumsi kalsium maka kualitas kerabang telur semakin baik. 


\section{Kesimpulan}

\section{KESIMPULAN DAN SARAN}

Berdasarkan hasil penelitan yang telah dilakukan dapat disimpulkan bahwa pemberiann kerabang telur sampai level $7.5 \%$ dalam pakan cukup berpotensi dalam meningkatkan produksi dan kualitas eksternal telur ayam ras dengan efisiensi pakan yang reletif baik.

\section{Saran}

Berdasarkan hasil penelitan yang telah dilakukan, disarankan untuk menggunakan kerabang telur sebagai bahan pakan ternak khususnya unggas guna mengurangi biaya pakan.

\section{DAFTAR: PUSTAKA}

Amrullah, I.K. 2003. Nutrisi Ayam Petelur. Seri Beternak Mandiri.Lembaga Satu Gunung Budi, Bogor.

Anggorodi, R. 1994. Ilmu Makanan Ternak Umum. PT. Gramedia. Jakarta

Anonim. 2012. Faktor Yang Berpengaruh Terhadap Naik Turunnya Produksi Telur http://disnak.jatimprov.go.id/web/.majalahinfovet.com

Anonim. 2017. Faktor Yang Mempengaruhi Produksi Telur Pada Ayam Petelur. https://cungit.blogspot.co.id/2017/09/faktor-yang-mempen garuhi-produksi-telur.ml.

A.O.A.C. 1990. Official method of analysis. 13th ed. Association of Official Analysis Chemist, Washington D.C..

Badan Standarisasi Nasional. 2008. SNI 013926-2008. Telur Ayam Konsumsi. Standar Nasional Indonesia. Jakarta.

Badan Pusat Statistik NTB. (2020). Produksi Telur Ayam Petelur Menurut Provinsi Tahun 2009-2019. Dinas Peternakan dan Kesehatan Hewan Provinsi Nusa Tenggara Barat. ,

Banong,S.2012. Manajemen Industri Ayam Ras Petelur. Masangena Press, Makasar.

Cahyono, B.1995. Ayam Petelur (Gallus SP) Pustaka Nusantara.Yogyakarta.

Harmayanda. P.O, Djalal. R, dan Osfar.S. 2016. Evaluasi kualitas telur dari hasil pemberian beberapa jenis pakan komersial ayam petelur. J-PAL, Vol 7 No 1.

Idris, S dan I. Thohari. 1998. Telur dan cara pengawetannya. Fakultas Peternakan. Universitas Brawijaya. Malang.

NRC, 1994. Nutrient Requirements Of Poultry. National Academy Pres. Washington D.C.

Rahardjo,Y 2009. Kenali Penyebab Turunnya ProduksiTelur. www.majalahinfovet.com/2a009/01/kenali-penyebab-turunnya-produksi-te

Syahputra.A. 2006. Pemanfaatan Campuran Tepung Kerabang Telur Dengan Semen Berbahan

Dasar Serat Kelapa sawit dalam Pembuatan Papan semen Partikel. Skripsi Fakultas Peternakan Bogor.

Scott,M.1., M.C.Nesheim and R.J.Young.1984. Nutrition of the Chickens.Publ. M.L.Scott.

Assoc.,Ithaca,N.YSirait, C.H. 1986. Telur dan Pengolahannya. Pusat Penelitian dan Pengembangan Peternakan. Bogor.

Stadellman, W.J. and O.J Cotteril. 1977. Egg Science and Technology. The Avi 
Publishing. Westport, Connecticut.

Sudarmono, A.S. 2003. Pedoman pemeliharaan Ayam Ras Petelur. Penebar swadaya.Jakarta.

Sudaryani, T. (2013). Kualitas Telur. Penebar Sadaya. Jakarta.

Sumiati,dkk.2016. Evaluasi Nilai Energi Metabolis Konsentrat Protein KLKS36, RK 24AA+, KR55 dan Pengaruhnya terhadap Produksi Telur Ayam Ras.

Sumiati,dkk. 2018. Pemampaatan Keong Mas dalam Pakan terhadap Produksi Telur Ayam Ras. Hasil Penelitian Dana PNBP Universitas Mataram.Mataram.

Tillman, A. D., H. Hartadi, S. Reksohadiprodjo, S. Prawirokusumo dan S.

Lebdosoekojo. 1989. Ilmu Makanan Ternak Dasar. Gadjah Mad University Press, Yogyakarta.

Wahyu.J. 1997. Ilmu Nutrisi Unggas. Gajah Mada University Press. Yogyakarta.

Yuwanta, T. 2010. Telur dan Kualitas Telur. Gadjah Mada University Press. Yogyakarta, dalam Ibnu Mundzir, Kualitas Telur Ayam Ras Petelur yang dipelihara pada Posisi Cage yang Berbeda, Skripsi Fakultas Peternakan Universitas Hasanuddin, Makassar.

Priyono, S.N. 1992. Pengaruh Lama Penyinaran dan Beberapa Level Energi Pakan yang sama terhadap Kualitas Telur Burung Puyuh. Skripsi S1. Fakultas

Sudaryani. 2003. Kualitas Telur. Penebar Swadaya. Jakarta.

Yuwanta, T. 2010. Telur dan Kualitas Telur. Gadjah Mada University Press. Yogyakarta. 